\title{
The Changing Relationship of Culture And \\ NATURE IN HEMINGWAY'S THE OLD MAN AND THE SEA: AN ECOCRITICAL STUDY
}

Nozar Niazi, Lorestan University, Faculty of Humanities, Department of English Language and Literature, Khorramabad, Iran

nozar_2002@yahoo.co.in

Original scientific paper

DOI: 10.31902/fll.36.2021.5

\begin{abstract}
Drawing upon ecocritical principles, this article makes an attempt to demonstrate the development from shallow ecological thinking towards a deeper ecological wisdom in the main character of Hemingway's The Old Man and the Sea. It argues that the marlin (the hooked fish) with 'instinctive intellect' and incredible traits throws a challenge to certain philosophical assumptions and cultural values held by the old fisherman, in a way that it makes him reconsider his long-held assumptions about his own intelligence, manhood, heroism and superiority over other creatures. The fisherman suffers from pangs of conscience when he realizes that his violation of spatial boundaries of the ocean and intrusion into the serene ecosystem of deep waters to find and kill the "noble creature' was a great mistake and, by suggestion, an ecological sin. By challenging the arrogance of humanism and questioning human's "unique position" in the universe, Hemingway suggests that any attempt driven by cultural motives intending to bring nature under control is against ecological spirit, and is eventually bound to failure. However, he simultaneously suggests that deep engagement with nature provides an opportunity to fathom the depth of human relationship with the natural world that brings deeper ecological awareness, as is the case with the old man of the novella.
\end{abstract}

Keywords: Ernest Hemingway, eco-criticism, culture-nature relationship, ecological sin, instinctive intellect

\section{Introduction}

Renaissance philosophy reinforced the proposition that the proper source of human knowledge must come from the study of human nature. By considering human nature as more significant and giving the physical nature a subordinate position, it laid the foundation of the binary opposition: culture/nature. Consequently, anything related to human ideals and artefacts represented culture and was celebrated, and everything natural became a sign of untamed barbarity that had to be controlled to serve humans. Drawing upon renaissance ideas, Rene 
Descartes (1596-1650) offered an influential account of the discrepancy between mind and body. "While separating mind from body, Descartes denied to animals the faculty of reason, and the whole range of feelings and sensations that he had attributed to thought. As a result, he saw animals as basically different from and inferior to humans" (Niazi, et al. 2013, 161). As an influential modern philosopher, Martin Heidegger blames Socratic philosophy "for constructing a rational subject that approaches the natural world as an object that serves a purely utilitarian purpose, a process that culminates (or reaches a disturbing nadir) in the Cartesian split" (Borlik, 2011, 9). In the early nineteenth century, a rigid separation between the 'natural' and the 'human' sciences began to be drawn. The compartmentalization of knowledge effected by this divide is, according to Bruno Latour (1993), central to what he terms the 'Modern Constitution', which he also believes "has sundered the human from the non-human realm, while defining society's relationship to nature predominantly in terms of mastery and possession" (Quoted by K. Rigby, 152). It is until relatively recently that some cultural and literary theorists influenced by post-humanist scholarship dared to cross the divide, bringing two realms of knowledge together and establishing interdisciplinary fields of studies with the aim of making better understanding of complex philosophical, cultural, social, and political issues of our time. Ecocriticism, ecofeminism, and postcolonial ecocriticism are good cases of the synergistic interaction of the 'human' and the 'natural' sciences. By moving beyond the deadlock of modernism and the arrogance of humanism, ecocriticism has made an effort to regain a sense of the inseparability of nature and culture, earth and artefact. William Rueckert is known to be the first to use the term 'ecocriticism' in his paper Literature and Ecology: An Experiment in Ecocriticism, in 1978. As a relatively recent approach to the study of literature, ecocriticism remains open to debate. However, researchers in the field still regularly cite Cheryll Glotfelty's pioneering statement made in Ecocriticism Reader (1996). She observes:

Simply put, ecocriticism is the study of the relationship between literature and the physical environment. Just as feminist criticism examines language and literature from a gender-conscious perspective, and Marxist criticism brings an awareness of modes of production and economic class to its reading of texts, ecocriticism takes an earth-centred approach to literary studies. (xviii)

Arne Naess, a Norwegian philosopher, originated the term 'deep ecology' in his paper, The shallow and the Deep, Long-Range Ecology Movement, in 1974. He defines deep ecology as a protest against 
anthropocentrism that underlies contemporary models of existence and life-styles. By laying out eight basic principles of deep ecology, he made great contributions to the richness of ecocriticism. Among those, relevant to our analysis of the novella under discussion, are principles such as: Validation of the inherent value of human and nonhuman life on Earth; Refusal of excessive human interference with the nonhuman, as it worsens ecological conditions; Protection of biodiversity or diversity of life forms; Condemning the reduction of the richness and diversity of life forms except to satisfy vital needs.

Based on the checklist provided by another eminent ecocritic, Lawrence Buell (1995, 7-8), an ecologically oriented work of literature should exhibit all, or some of, the following features:

1. The nonhuman environment is present not merely as a framing device but as a presence that begins to suggest that human history is implicated in natural history. [...]

2. The human interest is not understood to be the only legitimate interest. [...]

3. Human accountability to the environment is part of the text's ethical framework. [...]

4. Some sense of the environment as a process rather than as a constant or a given is at least implicit in the text. [...]

For the last few decades, almost every academic field of study has taken it upon themselves to actively play a constructive role in tackling global environmental degradations. As can be deduced from the above principles and definitions, ecocriticism is a literary response to a range of growing ecological issues of the late $20^{\text {th }}$ century. As a critique of anthropocentric modes of existence, this critical approach is committed to the protection of the natural world by actively engaging itself in raising awareness about cultural and philosophical issues that are known to be chiefly responsible for the status quo. It encourages literary writers to come up with creative-pragmatic ways to save the planet from ecological collapse. "All ecological criticism shares the fundamental premise that human culture is connected to the physical world, affecting it and affected by it. Ecocriticism takes as its subject the interconnections between nature and culture" (Glotfelty, xix). Thus, authors with ecological thoughts, by redefining the concept of nature in their artistic creations try to correct certain philosophical and cultural misconceptions by showing the tiny place of humans on the vast map of the universe. Also, by showing the interconnectedness of humans (their culture) and nature, they try to establish public support for the protection of the natural environment and harmonious coexistence 
between human and nonhuman, because they see the imbalanced relationship as the root cause of the ecological crises of our time.

Ecocriticism as a fairly recent critical approach to literature has been a part in the Hemingway studies, opening a new avenue for a fresh reading of the author's major works including The Old Man and the Sea. Valuable academic research has been conducted in an attempt to bring out green layers of the novella. Almost all published research conducted on the novella within ecocriticism framework can be divided, except for a few, into two opposing groups. The first group consider the novella as a pure representation of 'deep ecology' and have gone to such an extent to deem Santiago's epic return from his ocean voyage as an ecological triumph. The second group try to demonstrate Santiago's anti-ecological consciousness, taking it to represent Hemingway's ambivalent ecological thought. At the heart of the novella, however, lies a constant tug of war between culture and nature that is manifested through Santiago's thoughts and behaviour. I argue that any critique of Hemingway's ecological thought in the novella has to account for the dynamic, complex and paradoxical relationship between culture and nature as presented by the old fisherman and the marlin. Hollenberg's paper (2012) and Stephan's paper (2013) are among those few articles that have made commendable efforts to capture the dynamism, complexity, and the paradox that exists in the old man's relationship with the marlin. However, the present paper is an attempt to cover certain topics such as 'animal heroism', 'imperfection of human intelligence', 'Santiago's essentialist thinking', among other topics, which need to be dealt with specifically for a deeper appreciation of the work. It also introduces certain ecological concepts such as 'ecological repentance', 'ecological $\mathrm{sin}^{\prime}$ ', and 'ecological aesthetics' that can appropriately be added in an ecocritical discussion of the novella. It is the aim of this paper to examine the relationship between culture and nature as is portrayed in the novella within the ecocriticism framework. Using a descriptive method for analysing the novella, the research endeavours to explore Hemingway's particular perspective on human (culture)-nature relationship which can then be used as a criterion for evaluating the novelist's ecological concerns. Since it will be impossible to explore all aspects of the novella's changing dynamics of culturenature relationship by applying a single theoretical framework, the research freely draws upon various theoretical concepts of ecocriticism that are relevant to the purview of the present study in order to provide a wider avenue for exploration of the novella's hidden green layers. 


\section{General tension between culture and}

The Old Man and the Sea is a three-day epic account of the adventurous voyage of an old fisherman into the deep waters of Gulf Stream, and the challenges he has to face in struggling with a huge marlin and many hungry sharks. Hemingway introduces a poor fisherman who had to patch the sail of his skiff with flour sacks. He rowed in the Gulf Stream for nearly three months, day after day, and caught no fish. The narrator tells us that one evening, while he was sitting on the Terrace, "many of the fishermen made fun of the old man" (p. 3). In the very beginning, Hemingway portrays a competitive society where success and respect of a fisherman depends on the number of fish he can manage to bring into the market. Younger fishermen, representing modern culture, " spoke of her (the sea) as a contestant or a place or even an enemy" (p. 21). They respected her "only when the shark livers had brought much money" (p. 21). Thus, the sea is deemed merely as a resource for material exploitation. On the other hand, the old man "always thought of the sea as la mar which is what people call her in Spanish when they love her" (p. 21). His conviction in the "law of the sea' or Nature's law is reflected by his thoughts: "If she (the sea) did wild or wicked things it was because she could not help them. The moon affects her as it does a woman, he thought" (p. 22). The old man may look at the sea as an animate being with a romantic soul, but his love for the sea, as we come to know, is not deeply rooted in ecological thinking. He loves many natural elements for their beauty, company, help, guidance as well as sustaining his life, for their instrumental utility. They give him a sense of superiority as well, of heroism as a fisherman, all of which reflects shallow ecological thinking. However, in his last voyage, he is deeply moved by nature's indomitable forces and mysterious intellect in a way that certain philosophical misconceptions as well as baseless cultural values are demolished in his mind. The following discussions are an attempt to substantiate such claims.

\section{Violation of spatial boundaries of nature}

Fishing for the old man has always been a basic form of sustenance which, in Naess's sense (1974), is ecologically acceptable. However, the idea of proving himself "as the best fisherman" and "regaining his long lost pride" are grounded in cultural concepts and values that function as driving forces that propel Santiago's small skiff into deep and dark waters of Gulf Stream. For Santiago, small fish were of no account anymore and he searched only for a fish of enormous size to prove himself as the greatest fish hunter. A brief glance into his thoughts clearly reflects the fact: "Today I'll work out where the schools of bonito 
and albacore are and maybe there will be a big one with them" (p. 22). Santiago violates his usual contact with the sea by crossing its spatial boundaries and entering the aquatic wild life with a conscious effort and an aggressive assertion of will power. His statement bears witness to the fact: "His choice had been to stay in the deep dark waters far out beyond all snares and traps and treacheries. My choice was to go there to find him beyond all people. Beyond all people in the world" (p. 42). Consequently, his usual attempts as a fisherman turn into an adventurous voyage, throwing a challenge to the natural world of the ocean. In an epic fashion, and with astonishing endurance, the old man manages, after three days, to catch the huge marlin. His demonstration of professionalism, heroism, endurance, and determination are highly valued from cultural perspective. However, any attempt driven by cultural motives, intending to bring nature under control, as Hemingway suggests, is deemed against ecological spirit and is, therefore, bound to failure. The sharks as other forms of natural forces, however, do not let Santiago leave the scene of murder without first being punished. Although, with great anger, he refers to a galanos and says, "Eat that, galanos. And make a dream you've killed a man" (p. 111), his confession to Manolin reveals a different fact: "They beat me Manolin. They truly beat me" (p. 115). Eventually, the sharks take his 'trophy' away and he is left with sheer disappointment and a reduced sense of masculine pride. As Stephen rightly puts it, "The attenuation of the marlin's flesh corresponds to the attenuation of Santiago's manhood" (p. 89). We hear the old man repeatedly regretting his unwise decision to enter deep waters: "I shouldn't have gone out so far, Neither for you nor for me. I'm sorry fish" (p. 102). And a little further, he tells himself: "You violated your luck when you went too far outside" (p. 108). Santiago's offer of apologies to the marlin, as Hollenberg observes, are "constructed through spatial terms [...] hinging on the violation of space. To have gone 'too far out' is to navigate vast space without any selfawareness" (p. 41). Now, Santiago's statement, "The ocean is very big and a skiff is small and hard to see" (p. 116), conveys the fact that human culture, as symbolized by the small skiff, occupies a tiny place in the expansive space of universe as symbolized by the ocean. At this point, there is neither any trace of pride that Santiago showed at the beginning of the story while talking to Manolin and proudly calling himself "a strange old man", nor the blatant anthropocentrism that was reflected by statements such as, "Man is not made for defeat" And "A man can be destroyed but not defeated" (95). Having lost the battle to the sharks, he tells himself in a humble way: "It is easy when you are beaten. I never knew how easy it was. And what beat you he thought." Nothing," he said 
aloud. "I went out too far" (p. 112). The old man's intrusion into the serene ecosystem of the ocean and the severe response he receives from the indomitable forces of nature in return reflect Jonathan Bate's idea of natural forces, which he maintains "are responsive to our interventions in ways we can neither foresee nor control" (p. 447). The old man will certainly continue to fish in the Gulf Stream after his ordeal. However, as Stephens Observes, "the humbled state of grace he has achieved is a mature man's submission to a natural order in which humans can not presume dominance" (p. 92).

\section{Santiago's Essentialist Belief in his Profession}

At the very core of Santiago's thinking lies a great paradox, namely commingled senses of love and antagonism towards the marlin: "Fish I love you and respect you very much. But I will kill you dead before this day ends" (p. 46). The killing of a creature that Santiago loves and respects cannot be justified merely by reason of making a living, because people like Manolin and the proprietor of the Terrace are always ready to cater to his gastronomic needs. Santiago's thoughts confirm the fact: "The boy keeps me alive. I must not deceive myself too much" (p. 98) Therefore, there must be stronger motives which are to do with social and cultural practices that can explain Santiago's paradoxical statements as well as behavior. Perhaps a most convincing explanation lies in the fact that, as a fisherman, he holds an essentialist view towards his trade. Despite his interspecies love and sympathy, calling the marlin "my brother", he is still adamant to kill the fish at any price: "I wish I could feed the fish, he thought. He is my brother. But I must kill him and keep strong to do it" (p. 51). Santiago's love for the marlin is easily defeated by his essentialist - cultural mode of thinking. He is convinced that he is born to fish and that he cannot do otherwise: "Perhaps I should not have been a fisherman, he thought. But that was the thing that I was born for" (p. 42). In this way, the old man's essentialist thinking as a fisherman has become an integral component of his social identity that he feels obliged to protect. Killing the marlin, therefore, becomes indispensable despite Santiago's love for the 'noble creature'. Fishing for the sake of sustenance, in Naess's sense (1974), is compatible with the spirit of deep ecology. However, Santiago's competitive pursuit for the biggest fish in remote waters is not in line with ecological philosophy. The codes of his profession demands that he should not emotionally get involved in the act of killing, as it deters him from achieving his goal. The narrator sheds light on the fact in the following statement: "He was sorry for the great fish that had nothing to eat and his determination to kill him never relaxed in his sorrow for him" (p. 67). Professionalism, as a 
highly valued cultural practice, eclipses Santiago's sympathy for the fish. His maxim "I was born as a fisherman" can be understood as an attempt on his part to philosophically justify, at least for himself, that despite his willingness the marlin was destined to die. On the other hand, since Santiago's love for the lions is not affected by such essentialist thinking, he appreciates their inherent worth irrespective of their usefulness, and thus makes no distinction between his love for Manolin whom he treats like his son, and the love he has for the lions: "The lions played like young cats in the dusk and he loved them as he loved the boy" (17). However, towards the end of the story, Santiago starts seriously questioning his act of killing the marlin by considering it from broader ethical perspective.

\section{Imperfection of Human Intelligence}

Anthropocentric philosophy celebrates human intelligence and deems it as a determining factor that distinguishes human beings from animals. Santiago's intelligence puts him in a superior position by enabling him to devise clever plans against a giant fish that apparently has no plan and acts merely on instinct. In this way, a binary opposition takes shape between the fisherman as an intelligent being, and the fish as non-intelligent. Santiago values his own intellect highly and praises god for endowing him with more brainpower than the marlin and the sharks. However, in the course of the novella, new realities emerge as a result of the old man's engagement with the great fish that makes him question certain human values such as heroism and human intelligence, and by doing away with illusions about his right for dominance over the marlin and the sense of superiority he feels over other creatures. When Manolin asks the old man if he is still strong enough for a big fish, he says: "I may not be as strong as I think. But I know many tricks" (p. 15). Here, the word tricks refers to the intelligent plans the old man makes to subdue the fish that seemingly is without a plan. When Santiago kills the marlin, he tells himself: "I am only better than him (the fish) through trickery and he meant me no harm" (p. 91). As a stylistic strategy, the author repeatedly employs words with negative connotations that convey the meaning of 'intelligence' to undermine the positive cultural concept of the term. While addressing the marlin, the old man says: "Thanks God, they are not as intelligent as we who kill them; although they are more noble and more able" (p. 55) The suggestion is that human beings are better killers due to their intellect. Thus, a redefinition of the concept of intelligence is offered in terms of its destructive power in the natural world. It makes Santiago astonished to notice that the marlin had kept his mouth shut on purpose, having no food for two days, 
and patiently followed his own plan. After observing how marlin's 'instinctive intelligence' guided the fish to fight back in its own way, Santiago realizes that he has over-valued his own intelligence. In the following statement, he confesses that his idea of being more intelligent than a shark is perhaps an illusion: "The dentuso is cruel and able and strong and intelligent. But I was more intelligent than he was" (p. 95). And then comes the confession: "Perhaps not, perhaps I was only better armed" (ibid). On the other hand, despite years of experience, the old man is shown not fully prepared for the challenges he faces in the course of his expedition. Santiago's poor management for the big challenge raises questions about his intelligence capability. He suffers partly because of his failure to take the very basic stuffs that he will need during his journey: "I wish I had a stone for a knife. I should have brought a stone. You should have brought many things. But you didn't bring them" (p. 102). While having to eat the unsalted and row dolphin that made him feel 'miserable', he says: "I will never go in a boat again without salt or limes", and blaming himself for that, he continues: "If I had brains I would have splashed water on the bow all day and drying, it would have made salt" (p. 71). In this way, denouncing anthropocentric philosophy, Hemingway exposes the inherently imperfect nature of human intelligence and redefines it in terms of its damaging impact on the natural world.

\section{Towards Animal Heroism}

'The great DiMaggio', captain of the Yankees' baseball team, is Santiago's favourite player and source of inspiration. Apart from DiMaggio's great skill in playing baseball, what makes him in the eyes of Santiago so great a hero is his fighting spirit despite suffering from a bone spur in his heel. The narrator tells us: "He felt very tired now and he knew the night would come soon and he tried to think of other things" (p. 59) and immediately his thoughts are revealed: "I must be worthy of the great DiMaggio who does all things perfectly even with the pain of the bone spur in his heel" (ibid). He further recalls the time at Casablanca when he had gone one day and one-night arm wrestling with the strongest man on the docks. After beating the man, he remembers everyone on the docks calling him the champion. The old man shows great admiration for qualities like fighting spirit, heroism, strength, and tolerance. His idea of manhood is defined by such traits and finds expression in statements such as: "Man is not made for defeat" and "A man can be destroyed but not defeated" (p. 95). While struggling with the marlin, he proudly says: "I wish I could show him (the fish) what sort of man I am" (p. 55). However, this sense of superiority 
does not last long and is deflated by Hemingway's huge marlin, exhibiting almost all the traits and qualities the old man has valued throughout his life, and believing to be specific to 'Man'. When the marlin demonstrates such qualities, ironically enough, the fisherman becomes more determined to kill him: "I have never seen or heard of such a fish. But I must kill him" (p. 66). This is while he greatly regrets that "he has to kill his true brother" (ibid), and adds: "There is no one worthy of eating him from the manner of his behaviour and great dignity" (p. 67). What is significant here is the marlin's active role as a player in bringing about changes in Santiago's attitude towards other creatures. Santiago's confession, in this regard, is a case in point: "Man is not much beside the great birds and beasts. Still I would rather be that beast down there in the darkness of the sea" (p. 60). Having appreciated the marlin's inherent worth, but still being under the influence of his essentialist thinking to kill the fish, Santiago finds himself on an equal footing with the marlin. Addressing the marlin in his thought he says: "You are killing me fish. But you have a right to. Never have I seen a greater, or a more beautiful or a calmer or more noble thing than you, brother. Come on and kill me. I do not care who kills who" (p. 84). It may seem anti-ecological that Hemingway's marlin is denied a voice to speak for itself as some researchers including Yu Yan (2011) have argued. However, Hemingway portrays a marlin that speaks through action. The marlin is a silent actor, and the profound impact it leaves on the main character as well as the reader, conveys volumes of meaning. While still struggling with the fish and suffering greatly from fatigue and confusion, the old man, as usual, looks for ways to boost his morale. This time, he wishes to tolerate the circumstances like his animal hero, the marlin. He tells himself: "Keep your head clear and know how to suffer like a man. Or a fish" (ibid, my emphasis). Santiago's utterance presents a balanced consideration of human heroism along with animal heroism, a removal of human / non-human binary opposition, and thus points to a shift from anthropocentric mode of thinking towards biocentrism.

\section{Santiago's Feeling of Kinship with the Marlin}

Santiago's growing feeling of kinship with the marlin reaches its climax towards the end of the novella. This is particularly significant as it marks his highest level of ecological appreciation. Having been guiltstricken over the killing of the fish, he tells himself, "I want to see him (the fish), and to touch and to feel him. He is my fortune, but that is not why I wish to feel him. I think I felt his heart when I pushed on the harpoon shaft the second time" (p. 87). The old man does not look at the marlin merely as a 'fortune', a bulk of meat to be sold in the market 
any more. As is evident, through ethical relations with the fish, a heart to heart connection has been established. Referring to the fish, he says: "I am sorry that I went too far out. I ruined us both" (p. 107). He can no longer defend his act of killing based on old justifications. His interior monologue sheds light on the fact: "You did not kill the fish only to keep alive and to sell for food, he thought. You killed him for pride and because you are a fisherman" (p. 97). Here, the old man's accountability to the fish resonates with Buell's (1995) idea of human responsibility to the natural world, and becomes part of the novella's ethical framework. Suffering from the pangs of conscience, he keeps on questioning whether his act of killing was tantamount to committing a sin. Earlier he had confessed, "I am not religious", and his prayers appear mechanical and void of religious spirit, looking more like a business deal: "I promise to make a pilgrimage to the Virgin of Cobra if I catch the fish" (p. 56). It would be hard to see Santiago's sense of guilt emanating from a strong religious belief. Moreover, based on Christianity's doctrine, to kill a fish does not make one a sinner. Santiago's killing the marlin is an act against creation, because his sense of guilt results from what he has done to a fish as part of the natural world. Therefore, it can be deemed as an 'ecological sin'. He justifies his killing of a dentuso who attacked the marlin, and says aloud, "I killed him in self- defence" (p. 97). Marlin has now become 'self' and fisherman's feelings of pity and sorrow for the fish have reached their climatic point, and thus completed his sense of kinship with the creature. The concept of 'ecological aesthetics' as defined by Berleant $(2013,11)$, finds full expression through the old man's total immersions with nature (the marlin). According to Berleant, ecological aesthetics, as opposed to traditional artistic aesthetics, by rejecting the dichotomies between subject and object, involves the total immersion of the appreciator in the object of appreciation, which he calls engagement approach.

\section{Last Observation}

The observation made at the very end of the novella by a female tourist at the Terrace can be understood from an ecocritic's perspective. While looking down to the water among the empty cans of beer and dead barracudas and seeing the long massive spine of the marlin, the woman taking it for a shark, observes: "I didn't know sharks had such handsome, beautifully formed tails" (p.118). In response, her male companion says: "I didn't either". The statements metaphorically demonstrate the misconception that exists between the world of culture and nature. While the old man's deep contact with nature has given depth to his ecological awareness, such consciousness in the 
common culture, as presented by the two tourists, does not seem to exist. The marlin, as the 'noble soul of nature' is now turned into garbage among the empty beer cans polluting the water and doomed to be taken out with the tide. In the last line of the story, the narrator describes the lions moving freely and peacefully in the old man's dream. This could be a metaphorical portrayal of man- nature reconciliation.

\section{Conclusion}

The old man, with a conscious effort and an aggressive assertion of will power violates his usual contact with the sea by crossing its spatial boundaries and entering the aquatic wild life. His navigation over deep waters in search of the biggest fish is a competitive effort motivated by certain cultural concepts and values that have little to do with the fisherman's intention of earning a livelihood, but more to do with his idea of proving himself as the best fisherman and regaining his long lost pride. The old man's love for natural elements, as we come to know, is not deeply rooted in ecological consciousness in Naess's sense (1974), as he deems himself more intelligent than other creatures and shows a strong sense of superiority over them. In the course of his voyage, as a result of his confrontation with the huge marlin and many hungry sharks, the old man is deeply moved by nature's indomitable forces and mysterious intellect. The old man gradually develops great love and respect for the huge marlin as it exhibits traits and qualities that he has valued throughout his life, and believed to be specific to 'Man'. The old man's commingled senses of love and antagonism towards the marlin creates the core paradox in the novella. A most convincing explanation for such paradox, as was discussed, lies in the fact that, as a fisherman, Santiago holds an essentialist view towards his trade. It is manifested in statements like, "I was born as a fisherman" and has become a part and parcel of his social and cultural identity in a way that he feels obliged to protect.

Santiago's voyage from shallow waters into the deep ocean looking for an enormous fish, ironically enough, symbolizes the movement from shallow ecological thinking towards deeper ecological wisdom, by looking more profoundly into the actual reality of human relationship with the natural world and arriving at philosophically deeper conclusions. The marlin, as an active player in the novella with extraordinary fighting spirit and instinctive intellect, demolishes, in Santiago's mind, the pillars of anthropocentric edifice built on misconceptions about human intelligence, superiority and uniqueness in the world, before the fish is killed by the old man. The emphasis on the smallness of the skiff and the vastness of the ocean is a symbolic 
manifestation of this fact, suggesting the tiny place human (culture) occupies on the massive map of the universe. Having lost the battle to the sharks, the old man greatly regrets his violation of spatial boundaries of the ocean and killing the creature he loves. The growing sympathy for the fish reaches an empathetic point, where a spiritual connection is established between the fisherman and the fish. Santiago starts seriously questioning his act of killing the marlin by considering it from broader ethical perspective. Since the old man's feeling of sin and repentance cannot be justified based on Christianity's doctrine, the concepts of 'ecological repentance' and 'ecological sin' bear legitimate relevance for discussion in the novella.

Based on the preceding discussions, it can be concluded that Hemingway challenges anthropocentrism by redefining human intelligence in terms of its devastating impact in the natural world, and by questioning human's "superiority" and "unique position" in the universe. He shows that any attempt driven by cultural motives intending to bring nature under control is against ecological spirit, and is eventually bound to failure. However, he simultaneously suggests that deep engagement with nature would also provide an opportunity, as is the case with the old man, to fathom the depth of human relationship with the natural world and gain a deeper ecological awareness. Thus, Hemingway presents a spectrum of ecological consciousness starting from shallow ecological thinking towards an ever deepening ecological wisdom

\section{Works Cited}

Bate, Jonathan. "Living with the Weather". Studies in Romanticism. Vol. 35, No. 3, 1996, pp. 431-448.

Berleant, Arnold. "What is Aesthetic Engagement?" Contemporary Aesthetics, Vol.11, 2013 (available online).

Borlik, Todd. A. Eco-criticism and Early Modern English: Green Pastures. Routledge, 2011.

Buell, Lawrence. The Environmental Imagination: Thoreau, Nature Writing, and the Formation of American Culture. Cambridge University Press, 1995.

Glotfelty, Cheryll. "Introduction: Literary studies in an Age of Environmental Crisis" In The Eco-Criticism Reader: Landmarks in Literary Ecology, Edited by Cheryll Glotfelty and Harold Fromm. Athens, Georgia University Press, 1996.

Hemingway, Ernest. The Old Man and the Sea. Janzadeh Publishers. Tehran, 1996. 
Hollenberg, Alexander. "The Spacious Foreground: Interpreting Simplicity and Ecocritical Ethics in "The Old Man and the Sea". The Hemingway Review. Vol. 31, No.2, Spring 2012, pp. 27-45.

Naess, Arne. "The Shallow and the Deep Long-Range Ecology Movement: A Summery". Inquiry: An Interdisciplinary Journal of Philosophy. Vol. 16, No. 1, 1974, pp. 95-100.

Niazi, Nozar, et al. "An Ecocritical Reading of D.H. Lawrence's The Rainbow". Journal of Basic and Applied Scientific Research, Vol.10, No. 3, 2013, pp. 158-166.

Rigby, Kate. "Ecocriticism". Introducing Criticism at the 21th Century, Edited by Julian Wolfreys. Edinburgh University Press, 2002, pp. 151-178.

Stephens, Gregory and Janice, Cools. "Out Too Far: Half-Fish, Beaten Men, and the Tenor of Masculine Grace". The Hemingway Review. Vol. 32, No. 2, Spring 2013, pp. 77-94.

Yu, Yan. "The Call of the Wild: An Eco-Critical Reading of The Old Man and the Sea". Canadian Social Science. Vol. 7, No. 3, 2011, pp. 167-175.

\section{La relation changeante entre la culture et la nature dans Le Vieil homme et La mer d'Hemingway : Une étude éco-critique}

Cet article est une tentative de démontrer, d'un point de vue éco-critique, le développement d'une pensée écologique superficielle vers une sagesse écologique plus profonde dans le personnage principal du vieil homme et de la mer d'Hemingway. II fait valoir que le marlin avec « intellect instinctif » et des traits incroyables jette un défi à certaines hypothèses philosophiques et des valeurs culturelles détenues par le vieil pêcheur d'une manière qu'il lui faut reconsidérer ses hypothèses de longue date sur sa propre intelligence son héroïsme et sa supériorité sur les autres créatures. Le pêcheur souffre de douleur de conscience lorsqu'il se rend compte que sa violation des limites spatiales de l'océan et son intrusion dans l'écosystème serein des eaux profondes pour trouver et tuer la «noble créature» était une grave erreur et, par suggestion, un péché écologique. En défiant l'arrogance de l'humanisme et en remettant en question la " position unique " de I'homme dans l'univers, Hemingway suggère que toute tentative motivée par des motifs culturels visant à maîtriser la nature est contraire à l'esprit écologique et est finalement vouée à l'échec. Cependant, il suggère simultanément qu'un engagement profond avec la nature fournirait également l'occasion de sonder la profondeur de la relation humaine avec le monde naturel qui apporte une conscience écologique plus profonde, comme c'est le cas avec le vieil homme de la nouvelle.

Mots clés : Ernest Hemingway, éco-critique, relation culture-nature, péché écologique. 